\title{
'A Milestone in the History of Slovakia': Two Narratives about the 2015 Referendum on the Family in Slovakia*
}

\author{
ALICA SYNEK RÉTIOVÁ** \\ Faculty of Social Studies, Masaryk University, Brno
}

\begin{abstract}
This paper examines a discursive controversy that arose in Slovakia after a conservative civic association initiated a referendum to protect 'traditional families' against the supposed encroachment of LGBTI rights. The 2015 referendum represents a tipping point in the formation of a new Slovak conservative political front. In this article, meaning-making among actors civically engaged in the referendum is brought to light by re-constructing the deep cultural structures in which they are immersed. Drawing upon the strong programme in cultural sociology, I analyse the master narratives woven through the discourse of the referendum organisers and boycotters. These narratives are re-constructed from 20 semi-structured interviews with the engaged actors and a corpus of 82 written documents, such as blogs, speeches, and declarations concerning the referendum. The analysis employs the methods of thick description and the structural analysis of narrative genres. It shows that, first, the referendum controversy presents a clash between a narrative of social decline and a narrative of social progress. The narratives serve as moral regulators by deploying emotionally loaded images of nostalgia for 'traditional families' and a utopia of unconditional progress. Second, although both narratives interpret the referendum as a milestone in the history of Slovakia, they do so in different genres with specific implications for action. Using the example of the decision by referendum opponents to withdraw from the prereferendum debates, I demonstrate how narrative genres as implicit and deep cultural structures have the power to orient action and shape the contours of controversy.
\end{abstract}

Keywords: narrative, genre, culture, meaning-making, referendum Sociologický časopis/Czech Sociological Review, 2022, Vol. 58, No. 3: 309-333 https://doi.org/10.13060/csr.2020.047

\footnotetext{
* Acknowledgement: This research was financially supported by a specific research project at Masaryk University with project number MUNI/A/1359/2019.

** Direct all correspondence to: Alica Rétiová, Faculty of Social Studies MU Brno, Department of Sociology, Joštova 10, Brno 602 00, e-mail: retiova@mail.muni.cz.
}

(C) Sociologický ústav AV ČR, v. v. i., 2022

(C) Author, 2022 


\section{Introduction}

'Join us and go down in history. ${ }^{1}$ With these words, the newly formed conservative initiative Alliance for Family launched a mobilisation campaign for the 2015 Referendum on Family [Aliancia za rodinu 2013]. The referendum proposed a ban on gay and lesbian marriages, adoptions, and compulsory sex education in schools. ${ }^{2}$ This popular initiative was a manifestation of the conservative backlash against $\mathrm{LGBTI}^{3}$ rights and gender equality resonating transnationally as part of an anti-gender movement [Giebel and Röhrborn 2014; Paternotte and Kuhar 2017]. Using right-wing populist rhetoric, the movement representatives voiced concerns about the disruption of 'traditional families' and the negation of sexual differences that they believe endanger the preservation of humankind [Korolczuk 2016]. The escalation of anti-gender mobilisation into national referenda has been characteristic of post-communist EU member states, ${ }^{4}$ in which progressive EU policy collides with worries about the disappearance of 'traditional values' and Eurosceptic sentiments [Anić 2015; Kahlina 2015; Slootmaeckers and Sircar 2018]. Such disputes have admittedly polarised public discourse, leaving certain conservative and progressive sectors of society in an antagonist relationship and with little ability to cooperate on common matters [Ondrušek et al. 2017: 99; Sekerák 2015].

In this article, I explore the public controversy over the 2015 Slovak referendum from a cultural perspective. Social movement scholarship predominantly conceptualises culture as a set of cognitive schemas used to frame a matter of concern [Snow and Benford 2000] or as a toolkit of cultural practices employed strategically by engaged actors [Swidler 1986]. To complement these approaches, I follow the call to incorporate a broader notion of culture into movements and protest studies [Jaspers, Goodwin and Polletta 2001; Ullrich, Daphi and Baumgarten 2014]. This holistic cultural perspective does not limit culture to a partial area of social life but treats it in an anthropological sense - as a shared web of meanings that are not only cognitive and strategically used but are also uncon-

\footnotetext{
${ }^{1}$ All quotations from the data are the author's translations from Slovak.

2 The referendum was supposed to consist of the following questions: (1) Do you agree that no cohabitation of persons other than a bond between one man and one woman can be called marriage? (2) Do you agree that same-sex couples or groups shouldn't be allowed to adopt children and subsequently raise them? (3) Do you agree that no other cohabitation of persons than marriage should be granted special protection, rights, and duties which are only granted to marriage and married couples? (4) Do you agree that schools cannot require children to participate in education pertaining to sexual behaviour or euthanasia, if their parents or the children themselves do not agree with the content of the education?' The third question was later found to be in conflict with fundamental rights and freedoms and was not accepted by the Constitutional Court.

${ }^{3}$ Lesbian, gay, bisexual, transgender, intersex

${ }^{4}$ Similar referenda took place in Croatia (2013), Slovenia (2015), and Romania (2018).
} 
scious, symbolic, and emotional [Geertz 1973; Lévi-Strauss 1974]. It aims to reflect and bring to light the deep cultural realm and how it informs social action - providing motives and imbuing everyday life with meaning.

Drawing upon the strong programme in cultural sociology [Alexander and Smith 2003], I explore the deep cultural structures of the 2015 referendum controversy, re-constructing the master narratives underlying the conflict to better understand conservative vs progressive battles in general. How is the referendum narrated by the actors civically engaged in the controversy as either referendum organisers or boycotters? What kinds of arguments, images, emotions, and genres do these narratives deploy to make the referendum meaningful and significant? Additionally, I want to provide comparative insight into the narrations of referendum proponents and opponents. This objective stems from the prevailing trend in social movement scholarship to examine LGBTI activism [O'Dwyer 2012; Paternotte 2016] or anti-gender mobilisation [Paternotte and Kuhar 2017; Kováts 2017] as two separate phenomena. Moreover, the scarce comparative research on movements and counter-movements regarding gay rights is primarily based on the analysis of instrumental framing and strategies [Ayoub and Chetaille 2017; Fillieule and Broqua 2020]. However, my ambition is to compare and bring to the fore the non-intentional, implicit, and latent cultural repertoires within the conflicting movements that make their efforts meaningful and legitimate.

The meaning-centred analysis of data from 20 semi-structured interviews with civil society actors and 82 documents (including blogs, web content, declarations, media interviews and legislation) reveals two different master narratives in which the conflicting groups enwrap themselves: the narrative of social decline among the proponents and the narrative of social progress among the opponents. They delineate antithetical portraits of the development of society, eliciting moods such as nostalgia, hope, or frustration. Although both narratives portray the 2015 referendum as a milestone in the history of Slovakia, they apply different genres. While the referendum proponents lean towards apocalypticism, depicting the referendum as an emergency brake to deflect a civilisational threat, the opponents use the romantic genre to portray the referendum as an obstacle in the natural development towards an inclusive society. I argue that these genres have social implications, shaping the controversy in a specific way: first, the apocalyptic genre enables referendum proponents to narrate the referendum as a meaningful and relevant initiative; second, the less-exaggerated romantic genre of the opponents allows them to decide to withdraw from pre-referendum debates and undermine the significance of the proponents' narrative. The analysis shows the capacity of narrative genres to orient and enable action or, in this case, inaction. 


\section{Referendum background: actors, activities, opposition, and legal framework}

The Alliance for Family, an umbrella association of conservative NGOs, announced the referendum in the summer of 2014 after collecting over 400,000 signatures. ${ }^{5}$ The referendum was heralded as the 'protection of family' [Aliancia za rodinu 2013], and it incited a heated public debate, as several controversies accompanied it.

First, though presented as a secular initiative, ${ }^{6}$ the referendum was morally and financially backed up by the Roman Catholic Church ${ }^{7}$ [Smrek 2015]. The Episcopal Conference of Bishops of Slovakia mobilised people by depicting same-sex partnerships and gender equality as a 'culture of death' in pastoral letters to be read as homilies in Catholic churches across the country [Konferencia biskupov Slovenska 2013]. Second, the voters were mobilised to take a position on what had already become a law through the Amendment to the Act on Marriage ratified in June 2014, which defines marriage as the unique bond between a man and a woman ${ }^{8}$ [Mesežnikov 2015]. Therefore, the referendum could only confirm the status quo, which fostered disputes over its significance and the expenses incurred from the national budget concerning it. Nevertheless, the referendum petitioners feared the redefinition of marriage in the future because the Constitution still did not contain an explicit ban on same-sex marriage. It has resulted in a paradoxical situation in which 'the State is unable to prohibit same-sex marriage just because it does not regard bonds other than those based on a woman-man relationship as a marriage' [Sekerák 2017: 41]. Third, referendum organisers constantly downplayed the topic of LGBTI rights and voiced the protection of the traditional family to be the referendum's only purpose [Raučinová 2014; Tódová 2015]. In September 2014, Slovak president Andrej Kiska submitted the referendum questions for judicial review to verify whether the referendum violated fundamental rights and freedoms [Krošlák 2015: 152]. Consequently, by the decision of the Constitutional Court, the question suggesting that there should be no legal protection for cohabitations other than marriage was found unconstitutional and was excluded.

These three points were also emphasised in the referendum boycott engaging progressive NGOs, activists, scholars, and independent media. The public

\footnotetext{
5 The citizens of Slovakia can initiate the referendum by submitting a petition with minimum of 350,000 signatures of eligible voters [Spáč 2010: 188].

${ }^{6}$ The official status of the Alliance for Family is 'a civil initiative not bound to any ideology, religion, or political party' [Aliancia za rodinu 2013].

7 Slovakia is one of the most religious countries in Europe, with $62 \%$ of the population self-declared Catholics [SODB 2011].

8 This amendment to the Slovak Constitution was adopted by the parliamentary majority. However, it should be remarked that the legal solutions pertaining to the definition of marriage in the Slovak Constitution contradict Article 8 of the European Convention of Human Rights [Kużelewska 2019: 21].
} 
initiative 'Let's Say No to the Nonsense Referendum' organised a hunger strike in protest and launched a social media appeal depicting the referendum as a vote against human rights. Opponents united under the boycott campaign 'We Won't $\mathrm{Go}^{\prime}$ a month before the referendum, creating a paradoxical mobilisation for ignoring public voting. Thus, while the referendum organisers aimed to mobilise people for voting in the referendum, the opponents engaged in a demobilisation strategy to lower the voter turnout not to reach the $50 \%$ threshold to make the referendum results valid. By the date of the vote on 7 February 2015, the tension between referendum proponents and opponents had turned into a nationwide controversy drawing the attention of mass media. Eventually, even though all the referendum questions received over $90 \%$ support, the voter turnout at $21.41 \%$ was insufficient to make the results valid, similar to the outcome of the Croatian, Slovenian, and Romanian referenda on same-sex marriage.

However, although such popular votes may seem zero-sum, they are conflictmaximising [Kużelewska 2019: 23]. The referendum represented a tipping point in the crystallisation of a new conservative political front [Gajdoš and Rapošová 2018]. It brought the topic of same-sex marriages and civil unions into the spotlight and initiated unprecedented public debate [Rybár and Šovčíková 2016: 86]. It also created the possibility to articulate conflicting positions by setting the tone for further public disputes on values and human rights. ${ }^{9}$ Moreover, as this paper shows, while the low turnout points to the public's indifference towards the topic of LGBTI rights, media and civil society discourse on the referendum reveals greater polarisation of the conservative and progressive sectors of society.

\section{The role of narratives in social life}

This section introduces the theoretical background of the paper with a particular focus on the concept of narrative. Smith [2005: 28] argues that 'when events happen they are not treated in an isolated way, but rather are inserted into a broader narrative matrix that tells us what they mean'. The study of narratives is the study of conflict-maximising, the focus of the strong programme in cultural sociology [Alexander and Smith 2003]. Its proponents suggest examining culture as an underlying realm of social action and as the locus of meaning-making processes [Spillman 2002: 4]. Culture is conceived as collective common sense, a web of meanings people themselves have spun and are suspended in it [Geertz 1973]. Drawing from structuralist approaches in anthropology and linguistics [Saussure 1959; Lévi-Strauss 1974] and textual approaches to cultures rooted in Weberian Verstehen sociology [Burke 1941; Ricoeur 1973], the strong programme

\footnotetext{
9 The topic of same-sex partnerships and parenting continues to resonate in Slovak electoral campaigns, such as the latest parliamentary $(2016,2020)$ and presidential $(2019)$ elections.
} 
introduces 'structural hermeneutics' as a theoretical and methodological model. While structuralism seeks to identify patterns of meanings and construct a general culture theory, hermeneutics captures the temper and texture of meanings [Alexander and Smith 2003: 26]. Treating culture as a patterned and self-contained system of meanings makes it possible to grant culture relative autonomy by distinguishing it from social structure [Kane 1997]. In the analysis, culture stands as an independent variable with explanatory power [Alexander and Smith 2003: 12]. Accordingly, the narrative dimension of the referendum controversy is analysed as an autonomous realm with implications for action.

Narratives form a specific axis of meanings complementary to cultural codes in binary oppositions within the cultural realm. While binary codes, such as good-evil, active-passive, and rational-irrational, classify the world according to moral criteria, narrative structures allocate responsibility, agency, and causality [Smith 2005: 14]. Narratives are stories constructed and exchanged by people and communities through which they come to understand themselves and the world they live in; they carry meanings in a story-like structure that employs characters, space and time, plot, and a timeline [Kane 1997: 258; Smith 2005: 18]. Narratives provide explanations by representing events in cause-and-effect relations [Polletta 2006: 10]. According to Jameson [2001: 103], all historical events, despite their great complexity on a phenomenological level, pass through narrativisation and are accessible to us only in narrative forms. Different groups of actors, however, may narrate the same event in different ways. The event can be 'real', but what it means and what should be done about it is defined by a narrative genre that carries implications for social life [e.g. Jacobs 2001; Polletta and Bobby Chen 2011]. Romance, for instance, generates optimism, tragedy stimulates fatalism and resignation, irony opens space for social critique and innovation, and apocalypse legitimates exceptional acts as risks, sacrifice, or war [Alexander and Smith 2003: 25].

Drawing from structuralist poetics, Smith [2005] proposes a model of the genre to categorise formal genres according to their structural attributes: with greater polarisation in the moral sides of a story, motivation moves from mundane to ideals, the scope of the object of struggle enlarges, and powers of action increase (see Figure 1).

The model shows three narrative genres - low mimesis, tragedy/romance, and apocalypse - positioned on a scale of narrative inflation. Low mimesis represents mundane affairs, and it is the least inflated narrative genre because characters are slightly polarised with limited powers of action and the object of their struggles is local. Tragedy and romance adopt middle positions as they depict morally polarised characters with elevated powers of action and greater motivation to struggle for an object of national scope. Last, apocalypse represents the most inflated genre, with strong moral polarisation between characters motivated by ideals, endowed with extraordinary powers, and struggling for an object of global scope. In other words, the more inflated the narrative is, the greater the threat it predicts and the more it stresses the urgency to take action on it. 
Figure 1. The structural model of genre

LOW MIMESIS TRAGEDY/ROMANCE APOCALYPSE

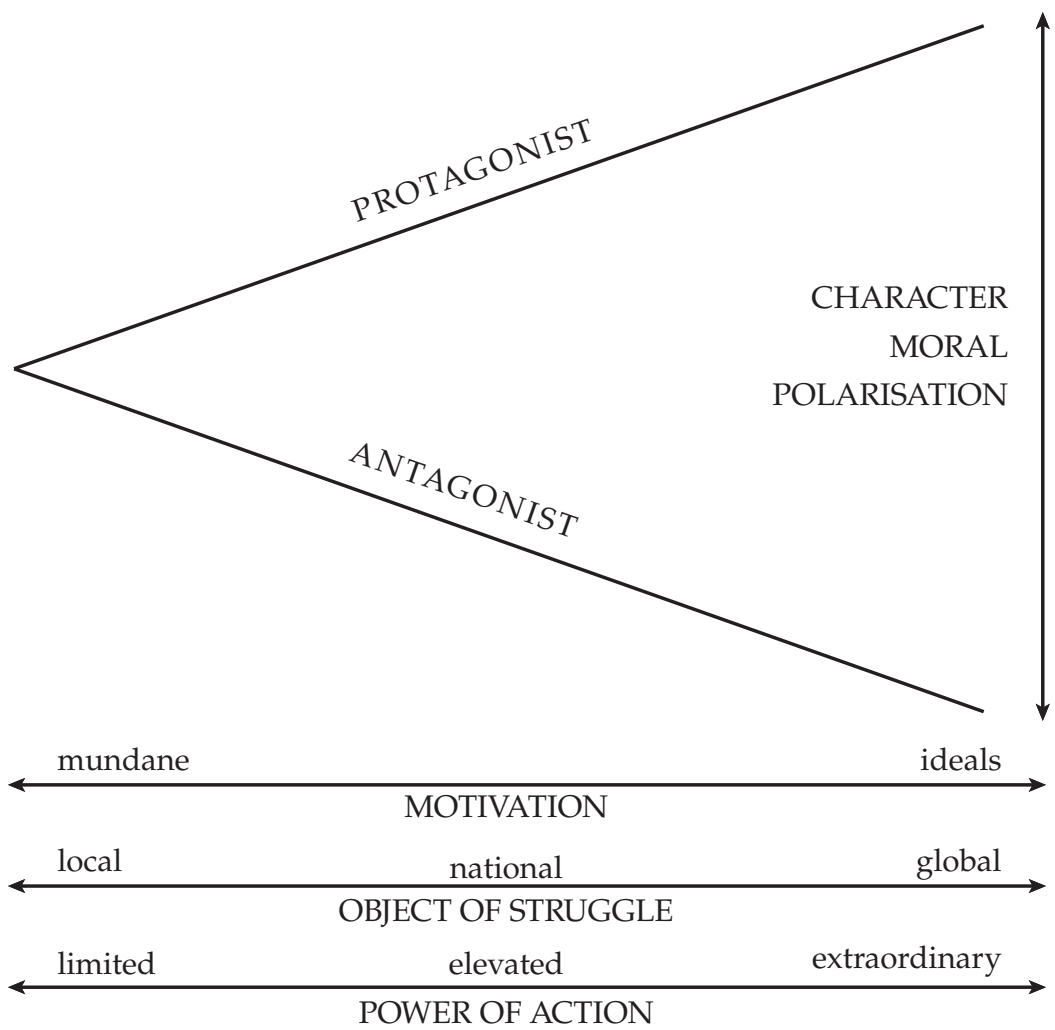

Source: Smith [2005: 24].

Unlike frames and other strategic speech acts, movement leaders do not use narratives to maximise their power; instead, they serve as a guiding mechanism, creating a meaningful context for action. The cultural-sociological analysis of narratives differs from frame analysis [Snow and Benford 2000] and the toolkit perspective on culture [Swidler 1986] along three dimensions. First, narratives are moral regulators enabling and constraining human agency. They align actions with ultimate purposes and implicitly or explicitly indicate the morally right thing to do [White 1980]. Second, narratives employ emotional registers evoking powerful passions, hopes, dangers, or triumphs [Barthes 1977: 124; see 
Jaspers 2009]. Thus, they bring feelings to the centre of the analysis of meaningmaking, whereas approaches that treat culture as a strategy tend to overlook emotions and overrate cognition. Third, the strategic use of culture also ignores cultural autonomy by disregarding that people first need to make sense of situations by referring to cultural models, which may lead to false cultural causalities [Kane 1997: 250-254].

Nevertheless, this paper does not aim to deny the relevance of frame analysis in the study of movements and conflicts..$^{10}$ Instead, it aims to illuminate the deeper and unconscious meaning-making processes of actors engaged in the referendum controversy, since movements not only use culture but also embody culture without always applying it [Ullrich, Daphi and Baumgarten 2014: 4]. It also aims to bring to the fore the cultural background in which the motivations and actions of the engaged actors are immersed. Drawing upon these premises, I analytically separate the cultural-narrative dimension of the referendum controversy with the objective of examining cognitive, moral, and emotional aspects of the narratives concerning the 2015 referendum that circulated within the media and the civil sphere.

\section{Data and methods}

Since meaning-making can hardly be measured regarding frequency or amount, this study employs qualitative methods of interpretation and reconstruction [Denzin and Lincoln 2011: 8]. I analysed 20 semi-structured interviews with proponents and opponents of the referendum and 82 written documents concerning the referendum. The selection of the participants and the documents was conducted using purposeful sampling, following a constructivist approach [Rapley 2014]. First, I delineated the case as 'the referendum controversy' to provide the research with a clear focus and coherence [Reed 2011: 103]. Second, I created a sample of 'information-rich' actors and documents from which I could learn a great deal about the case [Patton 2002: 230]. Third, I collected and analysed the data simultaneously to construct and re-construct an analytical puzzle until I reached theoretical saturation - until fresh data stopped sparking new theoretical insights [Thornberg and Charmaz 2014: 167]. Finally, after reaching saturation, the case appeared as a coherent web of meanings.

\footnotetext{
${ }^{10}$ For instance, examining the discursive strategies among the leaders of the Slovak Referendum on Family, Valkovičová [2017] has aptly pointed out how the actors use frames (e.g., 'collapsing European civilisation', 'threat to nation', etc.) to create a cleavage between 'depraved Europe' and 'pure/traditionalist Slovakia'. In another study, the critical frame analysis helped to identify the role of the ethics of care in narratives of sex education related to one of the referendum questions [Libáková, Valkovičová and Jesenková 2019].
} 
The interviews were collected between 2016 and 2018. I addressed civically engaged individuals ${ }^{11}$ who actively and publicly participated in the controversy, either as proponents or opponents of the referendum, by writing blogs, organising mobilisation campaigns, or administrating social media. The interview sample contained ten actors from each side of the dispute. Since the studied field is relatively small, considering the country's size and the selection of publicly known actors, I have chosen not to include a table with participant characteristics to maintain their anonymity. Regarding the type of engagement in the controversy, 18 out of 20 participants were engaged through non-governmental organisations with either conservative or progressive orientations, and 13 were main representatives. Nevertheless, 11 participants pursued a parallel career outside the civil society sector. During the interviews, I followed the principles of the 'comprehensive interview', based on empathy, with the aim of gaining deeper insight [Kaufmann 2010]; I also strived for the maximum possible standardisation of my approach towards all participants.

The second source of data was a corpus of documents written between December 2013 and February 2018. The selected documents were sorted into five categories: (1) blogs, commentaries, and speeches; (2) content of web pages; (3) declarations and open letters; (3) media interviews; (4) legislative documents; and (5) Church declarations. Out of 82 documents, 50 fell into the first category. The blogs and commentaries were published under the platform of national journals, with approximately half advocating pro-referendum positions and the other half espousing anti-referendum positions. The online content was collected from the official web pages of the 16 engaged NGOs. Out of the six analysed declarations, three were pro-referendum and the other three anti-referendum. ${ }^{12}$ Two out of four analysed media interviews were published in national dailies and the other two on web pages of the engaged movements. The legislative documents included three strategies discussed during the referendum campaign. ${ }^{13}$ Third, I analysed three pastoral letters written by the Episcopal Conference of Bishops of Slovakia to be read as homilies in all Catholic churches in the country.

\footnotetext{
${ }^{11}$ Since some of the interviewed actors do not want to call themselves activists, I use the term 'civically engaged individuals', as they are all engaged with civil society issue(s), working within civil society institutions.

12 The Alliance for Family Declaration (2013), Declaration of Conservatives after the referendum (2015), Declaration for Family before the parliamentary election (2016), Open Letter to the Government from Human Rights Organisations (2014), Declaration of theologist against the referendum (2015) and 'We Won't Go!' - Declaration of LGBT organisations before the referendum (2015).

${ }_{13}$ The Action Plan for Gender Equality in the Slovak Republic for the Years 2014-2019, National Strategy for Gender Equality in the Slovak Republic for the Years 2014-2019, and Nationwide Strategy for the Protection and Support of Human Rights in the Slovak Republic (2018).
} 
The data analysis entailed constructivist coding. I started with initial open coding to avoid forcing data into preconceptions and to stay open about the direction of further research; then, I used focused coding to synthesise the codes into tentative conceptual categories. Finally, I engaged in theoretical coding by bringing theoretical perspectives into the codes [Thornberg and Charmaz 2014: 156-159]. The analysis was conducted using Atlas.ti software. I also used thick description to grasp the complex nature of meaning making in all its colours, shades, and tempers [Geertz 1973]. Thick description is a meaning-centred approach to data analysis rooted in the epistemology of interpretive research, in which the researcher treats the collected data as an ensemble of texts saturated with meanings requiring constant attention to every detail. Following this premise, I created thick summaries of the data from interviews and documents to construct a complex and coherent picture of meaning-making about the referendum within the media and the civil sphere. The narratives about the referendum were re-constructed from the data organised into codes and summaries aiming to deliver an interpretive explanation ${ }^{14}$ of the referendum controversy [Reed 2011: 128]. Since meanings bear motivation for action and define the social context of action, their interpretation can provide a better understanding of the motivations underlying both sides of the controversy and an explanation of the actors' decisions to act accordingly.

\section{Narrative of social decline and narrative of social progress}

Public controversies often involve stories about the dangers of descent and the hopes of rescue [Smith 2005: 23]. This scenario played out in my findings. The Alliance for Family publicly asserted a narrative about the gradual regress of people's morals - the disruption of families, society, and, eventually, all of civilisation - and proposed a national referendum to help reverse such an impending future. The conservative movements sketched an image of social decay, generating feelings of nostalgia for the disappearing 'traditional' world of clear gender roles and heteronormative society. The referendum opponents articulated an alternative view of society. They pointed to the continuous, albeit slow, progress of society in recognising individual rights, solidarity, and freedom, seeing the referendum as a hindrance to such progress, an obstacle in the struggles for a better world that must be overcome. The utopian idea of progress, notwithstanding the backlash, imbued the narrative of progress with feelings of determination and hope that, however, could be easily interrupted by frustration caused by the conflict between expectations and reality. The following sections elaborate on these two master narratives about the referendum and the emotional registers they employ. ${ }^{14}$ Reed [2011: 23] considers thick description to be also the maximal interpretation of the
studied case. 
In December 2013, the Episcopal Conference of Bishops started to warn people through pastoral letters about spreading a 'culture of death' that endangers the natural, God-given order of things:

Followers of the culture of death come with a new 'gender ideology' ... They aim to assert the union of two men or two women as equal to marriage. By doing so, they create a Sodomite mockery that is contradictory to God's will and presupposes God's punishment. Through high-minded slogans, the disruption of family life is being asserted into society.

[Konferencia biskupov Slovenska 2013]

LGBTI and feminist activists were accused of disrupting 'traditional' - heterosexual - families by promoting so-called 'gender ideology' and a 'culture of death'. The allegory sowed the seeds of the master narrative of social decline that later permeated all referendum-promoting activities.

The narrative of decline was later shorn of its religious character, when the Alliance for Family initiated the referendum campaign, but the actors and the narrative's plot remained. For example, consider the following quotation from the blog of a conservative activist:

If the government will invest money in the analysis of curricula and teaching methodologies to 'eliminate unfair information about sexual orientation'; if it will uproot 'hetero-normativity', adjust birth numbers individually to avoid discrimination against transsexuals; if it will sexualise our children in an untimely way instead of investing in education about relationships, marriage and parenting, the development of children's talents and support of the disadvantaged, not only will it have to address and finance the treatment of various addictions but also Slovakia can await the fate of the Roman Empire. It was also rich and modern until it fell to the social support of homosexual partnerships and disappeared.

[Ocilková 2014]

By drawing a causal link between social acceptance of homosexual partnerships and the fall of the Roman Empire, the allegory of social decline escalates dramatically. The narrative allows for future predictions using a particular interpretation of the past.

In the interviews, the predictions of catastrophic decline were implied rather than communicated straightforwardly:

Family is crucial, and I perceive that step by step - if we look at statistics - the family situation, its functionality, marriage stability or, for instance, reproductive function are worsening in society. For example, few children are born, and it is a problem, an indicator that something is not right.

Interview, referendum proponent, male, 38, 6 February 2018 
Although this participant did not explicitly blame LGBTI politics for the decline, he suggested that society has moved out of the realm of the ordinary, predicting further deepening of these problems. Another participant shared her worries about society being distorted by overlooking gender differences:

Boys and girls should be educated differently, not all in the same way. Because the duties of women are totally different from those of men, but society throws them into one bag ... So, it is all distorted in this society, and I hope it will change one day.

Interview, referendum proponent, female, 47, 9 February 2018

The participant described her concerns using the Slovak phraseme 'to throw into one bag', which implies the resignation of sorting fundamentally different things. After progressive feminist politics had problematised the taken-for-granted model of family based on a heterosexual partnership and fixed gender roles, nostalgia for an imagined golden age, when everything was clear and simpler, began to resonate and nourish a quest to establish firmer foundations [Paternotte and Kuhar 2017: 14]. Non-heterosexual identities, LGBTI movements, and gender equality politics have reawakened the fluidity and complexity of reality, disturbing neo-conservative movements [Harari 2019]. The narrative of decline elicits feelings of nostalgia for a disappearing world, in which everything was clear and simple - when a family consisted of a mother, a father and their children, and when men were men and women were women.

The assumption that what was once all right is nowadays disappearing results from the politics of nostalgia based on the myth of an ideal past. Narrative relies on essentialism to understand history and naturalises past values and beliefs to formulate a 'normative judgement of certain social practices and relationships in the modern world' [McCutcheon 1997: 34]. This judgement is emotionally loaded. The past depicted in narratives elicits emotions of lost happiness and emphasises nostalgic disillusionment for supposed decay:

It is something kind, human, intimate, beautiful that gives me a feeling of the beauty of life ... Slovakia is rather conservative, and I think that it is our task in Europe to speak about these still present values because in many Western countries, it has already shifted.

Interview, referendum proponent, female, 58, 14 June 2016

The narrative of decline is exponentiated by a nostalgia for disappearing 'traditional values' that are glorified as beautiful, kind, joyful, heartwarming, true, and simply right. The appeals to preserve traditions are born in reaction to a constantly changing modern society, as a response to a novel situation, to structure life as unchanging and foreseeable [Hobsbawm 2000: 2].

The story about the 'traditional family' evokes an image of a golden age that ought to be re-established to recover the well-being of society and the happiness 
of its members. However, it is rather a myth than a memory of how things were because family models have been changing constantly. In fact, the family of a married couple and their biological children sharing together a common household has become an exceptional model since the late 1960s and the beginning of the 1970s an exceptional model [Ondrejkovič and Majerčíková 2006: 10] $\cdot{ }^{15}$ Moreover, the image of the 'traditional family' combines characteristics of families from different historical eras, such as the expectation for a woman to fulfil both the roles of mother and wife equally. Since the mother-child relationship was accentuated in the mid-19th century in white, middle-class families and the maintenance of romantic and sexual intimacy between partners was first articulated in the 1920s, the traditional family 'is an ahistorical amalgam of structures, values, and behaviours that never co-existed' [Coontz 1992: 9]. The appeal to preserve tradition condenses the nostalgia of decay aimed at delegitimating calls for recognition of same-sex partnerships and alternative family models.

\section{A utopia of progressive tomorrows}

While the narrative of social decline situates the vision of a golden age in the past, the narrative of social progress among referendum opponents finds its ultimate destination in the future, implying the development of a better world. The representatives of progressive politics who formed the active referendum opposition predict greater inclusion of minorities and respect for human rights in liberal democracies, as the following two quotations from media commentaries illustrate:

To use nature as an argument is ridiculous and embarrassing. These kinds of arguments were maybe relevant centuries ago but not nowadays. Nowadays, women fly into space, manage prestigious scientific workplaces and universities, and lead world powers. And no one will stop this development anymore.

[Pietruchová 2014]

The argumentation against evolutionary theory or against heliocentrism based on the Bible has become unsustainable. It will be similar to argumentation against homosexuality.

[Prostredník 2017]

In the first quotation, a gender equality expert points out the progress in women's emancipation to emphasise the outdated character of the arguments used by the referendum proponents. In the second, a progressive theologist anticipates the

${ }^{15}$ For a closer discussion on changes in family models and intra-household division of labor in Slovakia and Czechia see, for example, Možný [2002] and Mendelová [2014]. 
end of the conservative backlash by comparing it to past struggles against what is nowadays considered a matter of fact.

The narrative of progress implies a world of universal human rights and unconditional recognition of individual authenticity, echoing the ideals of the culture of modernity [Wagner 1994]. Such a notion of the world is the utopia of liberal humanitarianism, which originated as a belief in the arrival of a thousand years of God's kingdom, was later secularised, merged with French revolutionary ideals, and has served until the present time as a moral regulatory device [Mannheim 1936: 219-224]. Just as nostalgia for the 'traditional family' delivers a normative judgement of the present time through the narrative of decline, a utopian vision of a better tomorrow sets the criteria for assessing the current situation through the narrative of progress. It allows for the visualisation of a scale of development in the world and for judging the current state of affairs according to it, as indicated by a commentator for a progressive daily:

From its beginning until its end, the whole referendum hysteria is proof of the undeveloped and backward Slovak democracy. In a developed liberal democracy, in the first place, nobody would think about initiating a referendum that suppresses the rights of a group of citizens ... Building democracy is a long-term process full of obstacles. There is a saying that those who do not fight for democracy do not deserve it.

[Bučko 2015]

The referendum boycott results from a broader narrative of progress through which it can be interpreted as an act of overcoming obstacles and the actualisation of progress itself. The image of a gap in the development between (Western) democracies and Slovakia can serve as a push factor and an indicator regarding the next course of action.

The utopia of progressive tomorrows elicits feelings of hope and determination that are classified as moods with the capacity to 'affect our means for carrying out political ends' [Jaspers 2009: 85], which, in turn, stimulate action by providing actors with confidence and a vision of success in achieving their goals:

I truly hope that young people who have the opportunity from an early age to be free concerning this topic and support each other in groups where the others give you the idea that: 'you are absolutely alright; you only live in a fucked-up society'. Then, these people will be those who will gradually get to the point when this [idea] will be a matter of course, and they will change society only by that matter of course, you know?

Interview, referendum opponent, male, 39, 27 November 2017

Nevertheless, when utopian vision sharply contrasts with the real situation, feelings of great hope may eventually result in a loss of motivation and fatigue. This applies especially to highly engaged individuals - volunteers and activists - 
whose motivation by the vision of progress collides with the limited possibilities for pursuing their goals:

I, actually, thought that after 15 years of work in this sector, we would get further. That, for example, there would be at least an elementary civil union law. This is what I perceive as very demotivating. It is demotivating because we keep repeating - in arguments, words, strategies, activities... It is only about constant repetition.

Interview, referendum opponent, female, 39, 12 May 2016

Although contradictory in nature, feelings of hope and demotivation are two sides of the same coin, both nourished by a utopian vision of inevitable progress. Great determination can be easily transformed into resignation after not seeing the results of one's work. The unsuccessful lobbying for institutionalisation of a civil union law for the last 20 years is a significant source of fatigue within Slovak LGBTI activism. ${ }^{16}$

Altogether, narratives of decline and progress provide groups of referendum proponents and opponents with different understandings of the world. Moreover, by employing visions of ultimate goals and colourful emotional registers, narratives embody the capacity to motivate actors to adopt a certain position in the controversy and act accordingly.

\section{The apocalypticism of decline, progressive pushback, and the implications of genres}

Whether narrated as a way to prevent decline or to slow down progress, the referendum is depicted by both narratives as a decisive moment for the future of Slovakia. The engaged actors narrate the referendum as a historically significant breakthrough moment - a milestone in the country's history. For example, consider the following quotations, the first from the official declaration of the Alliance for Family and the second from the main anti-referendum initiative 'We Won't Go':

Join us and go down in history. We want and will protect family, marriage, and children as long as it is possible. Join us, and together, we will create a milestone in the history of Slovakia! Together, we can stop the ideology against the family from spreading across Europe.

[Aliancia za rodinu 2013]

\footnotetext{
${ }^{16}$ The first petition for civil unions in Slovakia was initiated by the civic association 'Inakost' in 2006, but the legislative proposal was rejected at the first reading in 2008. The liberal party 'Sloboda a solidarita' repeatedly submitted drafts of civil union law in 2012 and 2018, but again both proposals were rejected.
} 
My decision not to vote is crucial for the future character of our country: whether it will protect our rights only because we are human beings or whether there will be a space for spreading fear, hate, and creating other than secular rules.

[Nejdeme.sk 2015]

Inflated narrative genres reinforce the urgency of the calls of both sides of the controversy. They both represent the referendum as an event exceeding the mundane state of affairs and transgressing the limits of the present time.

The narrative of decline approaches apocalyptic narration much more than the narrative of progress. Apocalypse is characterised by an extraordinary drive for action and high moral impulses [Smith 2005: 21]. The referendum proponents predict an upcoming catastrophe, which can be averted by voting in the referendum. The apocalyptic genre stimulates a vision of the fight against time, which stresses the urgency to act, as articulated by the chair of the Alliance for Family before the referendum:

Who knows how much time is left? ... The European Parliament pushes member states without laws on civil unions to recognise civil unions formed abroad legally. How long will Slovak politicians be able to withstand this pressure? We do not know.

[Chromík 2014]

Furthermore, through the expression 'culture of death' [Konferencia biskupov Slovenska 2013] or 'dying out Europe' [Chromík 2017], the fate of humanity as a whole is at stake. Therefore, the apocalyptic genre allows for extraordinary powers of action, such as the national referendum. The referendum voters are addressed as heroes who self-sacrifice for the good to destroy the evil. The following quotation from a blog post reflecting on the referendum after three years illustrates such moral polarisation symptomatic for apocalyptic narratives:

We wanted to give people the opportunity to choose good or evil. So that they could make their own decision and not let elites decide for them. And we succeeded! Almost a million people went out in the frost and ice to testify before the whole of Slovakia about what they think of family. The politicians did not decide for them. They did. This will not be forgotten. Everyone who self-sacrificed and decided for the good has also realised this in their personal life.

[Chromík 2018]

Finally, apocalypticism is also reinforced by feelings of nostalgia for a disappearing 'traditional world', loaded with positive emotions, which is now in danger of extinction.

In contrast, the narrative of progress employs romance and tragedy as narrative genres. Since it is capable of generating moods of either hope or resignation, it can also vary between romance and tragedy. The theme of ascent to a 
Figure 2. Narrative of progress and narrative of decline categorised according to genres

$\begin{array}{ccc} & \text { NARRATIVE OF PROGRESS } & \text { NARRATIVE OF DECLINE } \\ \text { LOW MIMESIS } & \text { TRAGEDY/ROMANCE } & \text { APOCALYPSE }\end{array}$

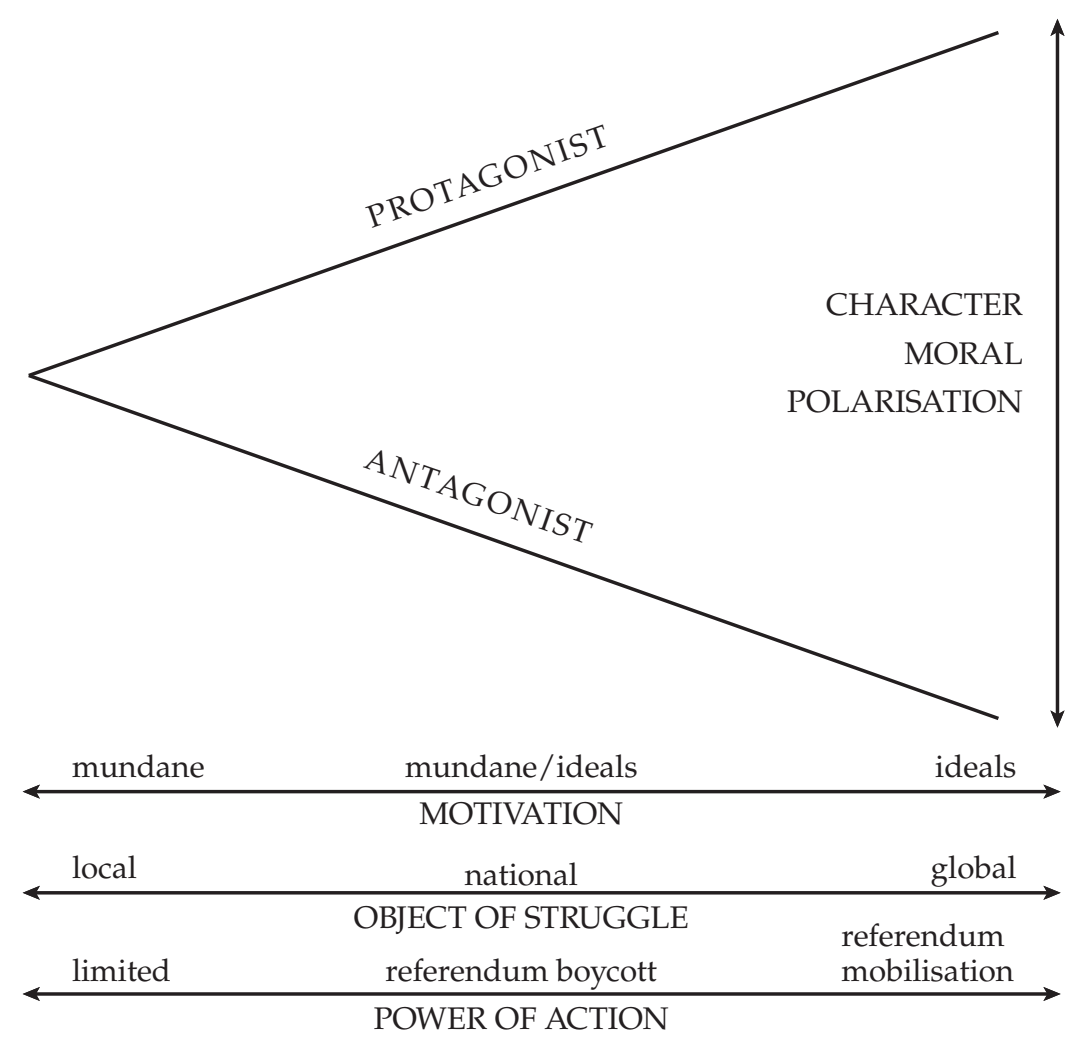

Source: Smith [2005: 24]; the analysed narratives categorised by the author.

better world is characteristic of both romantic and tragic genres [Frye 1976: 129 in Smith 2005: 26]. These genres differ in their emotional charge but match the structural characteristics, situated in the middle position on the scale of narrative inflation, between low mimesis and apocalypse. In this regard, the motivation for action that the narrative of progress sets is a combination of the mundane matters typical of low mimesis and the abstract ideals characteristic of apocalypse and myths. The referendum opponents articulate both types of motivation in the interviews - they point out the practical, everyday life problems of same-sex cou- 
ples that they aim to eliminate and also abstract ideals such as freedom, equality, and dignity:

We have been dealing with $x$-cases when a couple pays together a mortgage, but the primary heir is the family. And I have, for example, a very good friend whose partner from a ten-year relationship died, and if his family wants, it can gain all the money through the courts.

Interview, referendum oponent, female, 32, 18 September 2017

The most important value for me - for which I have been doing all of this my whole life - is equality and dignity. Because when we are equal and have the same starting positions, we respect each other, and we have dignified living and dignified lives. That, I think, is all we need.

Interview, referendum oponent, female, 55, 9 August 2016

By adopting the middle position, romance and tragedy make room for both types of motivation (see Figure 2).

Figure 2 shows the characteristics of the romantic-tragic genre within the narrative of progress, compared to the apocalyptic genre evident in the narrative of decline. While referendum proponents are much concerned about the fate of the world, opponents articulate national interests, making comparisons between the level of inclusion of LGBTI people in Slovakia with other - more developed countries through the narrative of progress. In this respect, their narrative defines the national object of struggle. Moreover, the powers of action that the narrative of progress stimulates are elevated but not as extraordinary as in the case of the apocalyptic narrative of decline. Since the referendum boycott aims to demobilise the public and calls for inaction, it does not require raising exceptional powers or legitimate exceptional acts such as the national referendum.

The genres of the referendum narratives also shape the overall dynamics of the controversy. First, the intense moral polarisation of the proponents' apocalyptic narrative allows them to tar their opponents with a morally polluting brush. Whereas they are depicted as righteous protagonists of the narrative of decline, the referendum opposition is accused of hypocrisy and hatred:

They [LGBTI activists] do not adhere to any principles; they would tell whatever is convenient for them as the right ideologues and recipients of financial grants. They speak of hatred against them, but they hate others. They speak of falsehoods of others, but they themselves lie, misrepresent, and mislead. They say they are being hurt, but they hold a cane in their hands to beat everyone with a different opinion.

[Lučanič 2015]

Like antagonists in a morality play, the referendum opponents are stigmatised as the embodiment of evil. However, their reaction to such attacks is not simply a 
switch in the moral coding of the story. Since the narrative of progress among the referendum opponents is less inflated than the narrative of decline, it allows the referendum opponents to 'prick the balloon of apocalypticism through redescription of objects, actors, and motivations' [Smith 2005: 27]. The genres of romance and tragedy, which the narrative of progress employs, are not so intensively polarised into absolute good and evil. Thus, they enable opponents to talk down the apocalyptic decline the referendum proponents portray. By doing so, they undermine the credibility of the referendum as such. An example of these implications of genres can be found in the development of the controversy a month before the referendum.

In January 2015, the referendum opponents, represented mostly by LGBTI activists, made a public statement about their withdrawal from discussion with referendum proponents. The statement was the result of a deliberative strategy formulated after a series of discussions within the opposition. In the statement, the opponents expressed their concerns about societal polarisation, in which referendum proponents kept repeating already refuted arguments [O médiách.com 2015]. One of the research participants described this shift as follows:

We have tried very hard, even during the referendum, to get rid of the label of 'the other side' of the dispute. At one point, we actually left the discussion because they [referendum proponents] had created the picture of a villain - a child abuser. So, we took a step back, since we can't be a sparring partner in their heated discussions as we do not represent any child abusers.

Interview, referendum opponent, female, 39, 12 May 2016

The withdrawal of the opposition from the debates was facilitated by the lessinflated genre of the underlying narrative of progress within which they operate. The opponents could refuse to engage with referendum proponents further because romance and tragedy leave some space for compromise or flexibility in action. By rejecting the label of 'the other side', the referendum opponents challenged the image of irreconcilable sides fighting for public attention. Their resignation expressed a refusal of the fundamental opposition between good and evil defined by the narrative of decline. Moreover, the narrative of progress, driven by the hope for a better world, enabled the opponents to maintain the inclusion of LGBTI people as their primary objective and to leave the pre-referendum struggle as a secondary concern.

In short, narrative genres shape the dynamics of the referendum controversy. The apocalyptic genre enables the referendum proponents to legitimise the importance of the national referendum, despite that it only confirmed the status quo and bore illiberal foundations [Gajdoš and Rapošová 2018]. While referendum mobilisation requires a highly inflated narrative about salvation from an apocalyptic decline, the demobilisation endeavours of the referendum opposition correspond to the moderately inflated genres of romance and tragedy. 
These moderately inflated genres enable the opposition to talk down the threat aligning the referendum's issues with mundane things and practicalities, shrinking the object of struggle, and undermining moral polarisation. In this way, the meaning-making processes in media and civil discourses operate through and within the narratives and their genres, which prove capable of drawing attention to certain issues, providing them with greater or lesser significance and enabling or disabling action or inaction.

\section{Discussion and conclusion}

This article has brought to the fore the narratives circulating in media and civil discourse about the 2015 referendum in Slovakia - a narrative of social decline among civically engaged referendum proponents and a narrative of social progress among civically engaged opponents. In addition to the contrasting visions of decline and progress, the analysis has shown how the narrative of decline employs an emotional register of nostalgia for the disappearing 'traditional world'. In contrast, the narrative of progress highlights the utopia of a better world to come. Moreover, different narrative genres have been identified: the narrative of decline is articulated in the genre of apocalypse, and the narrative of progress manifests through the genres of romance and tragedy, based on the emotional charge of either hope or frustration. Finally, the culturally sensitive analysis adopted in this study draws attention to the deep cultural realm as a locus of meaning-making to provide a better understanding of the dynamics of the referendum controversy. However, this does not mean that other factors, such as positioning within the social structure, power struggles, and the instrumental rationality of social actors should be dismissed. On the contrary, I suggest that structural and cultural perspectives should be treated as complementary rather than competing analytical models.

Narratives represent cultural mechanisms in the referendum controversy in several ways. First, they infuse the referendum within certain interpretations of the past and the future, thus filling it with special significance - the referendum is depicted as a 'milestone' in both narratives because participation in, as well as disregard of, the referendum is narrated as bearing future consequences. Second, the emotional load of the narratives precipitated by either nostalgia or the utopian longing for a better world evokes powerful moods that stimulate or impede action. Third, narrative genres have implications for action. While the apocalyptic narrative of decline helps to legitimise the national referendum as an exceptional act, the romantic/tragic narrative of progress can undermine apocalypticism by leaving space for moral transformation and flexibility in action. Through the example of the withdrawal of referendum opponents from pre-referendum debates, I have shown how the less-inflated narrative of progress enabled the opponents to redefine the positions of the conflicting sides and challenge the referendum's legitimacy. In this regard, the controversy around the 2015 referendum about gay 
and lesbian family rights is not merely a legal but also a symbolic dispute. It is driven by the narratives concerning the referendum to infuse action with meaning, elicit emotion, and provide motives and drivers of action.

The contradictory narrations about 'social decline' and 'social progress' can also further highlight the process of deepening polarisation between conservative and progressive sectors of society. Narratives provide conservative and progressive positions on LGBTI rights and gender equality with a coherent and self-contained cultural meaning system - the logic of a story. Through this logic, the referendum can be easily turned into a meaningful and significant event - as either an emergency brake against the decline or as an obstacle that must be overcome in the path towards progress. This article aims not to explain why some actors adopt conservative positions while others embrace progressive ideas, nor to analyse the referendum results or public opinion on LGBTI rights. It is, however, to provide a careful elaboration of the cultural background meanings - arguments, emotions, and images - by which the controversy is driven in the media and the civil sphere, but which are not always reflected and examined. The example of the strategy of the referendum opponents to leave the pre-referendum debates documents how deliberate action does not emerge ad hoc but stems from cultural backgrounds as the locus of meaning-making. Focusing on narratives as complex meaning structures, I have shown how culture provides unconscious mechanisms with the capacity to inform and enable action and inaction.

ALICA SYNEK RÉTIOVÁ is an assistant professor at the Department of Sociology, Masaryk University, where she was also a PhD student at the time of writing this paper. Her research interest lies in cultural sociology and social theory. Her current research activities are focused on public controversies around topics of LGBTI rights and migration.

\section{References}

Alexander, J. C. and P. Smith. 2003. 'The Strong Program in Cultural Sociology: Elements of a Structural Hermeneutics.' Pp. 11-26 in The Meanings of Social Life: A Cultural Sociology, edited by J. C. Alexander. Oxford: Oxford University Press.

Aliancia za rodinu. 2013. 'Vyhlásenie Aliancie za rodinu.' (Declaration of the Alliance of the Family) Aliancia za rodinu, 12 December. Retrieved 31 May 2018 (https://www.alianciazarodinu.sk/o-nas/vyhlasenie-aliancie/).

Anić, J. R. 2015. 'Gender, Gender "Ideology" and Cultural War: Local Consequences of a Global Idea - Croatian Example.' Feminist Theology 24 (1): 7-22, https://doi.org/10.1177/0966735015593434.

Ayoub, P. M. and A. Chetaille. 2017. 'Movement/Counter-movement Interaction and Instrumental Framing in a Multi-level World: Rooting Polish Lesbian and Gay Activism.' Social Movement Studies 19 (1): 1-17, https:// doi.org/10.1080/14742837.2017.1338941.

Barthes, R. 1977. Image-Music-Text. London: Fontana Press. 
Bučko, A. 2015. 'O čom naozaj svedčia výsledky referenda?' (What do the referendum results really testify to?) Denník N, 8 February. Retrieved 17 September 2019 (https://dennikn.sk/blog/44824/o-com-naozaj-svedcia-vysledky-referenda/).

Burke, K. 1941. The Philosophy of Literary Form. Berkeley, CA: University of California Press.

Chromík, A. 2014. 'Prečo sa chceme obesit?' (Why do we want to hang ourselves?) Blog SME, 7 March. Retrieved 25 June 2019

(https://chromik.blog.sme.sk/c/350775/Preco-sa-chceme-obesit.html)

Chromík, A. 2017. 'Vina mužov.' (Blame the men) Postoj, 11 May. Retrieved 31 May 2019 (https://blog.postoj.sk/23721/vina-muzov).

Chromík, A. 2018. 'Anton Chromík: tri roky po referende.' (Anton Chromík: three years after the referendum) Slovenský dohovor za rodinu, 7 February. Retrieved 31 May 2019 (http://slovenskydohovorzarodinu.sk/antona-chromik-tri-roky-po-referende/).

Coontz, S. 1992. The Way We Were: American Families and the Nostalgia Trap. New York: Basic Books.

Denzin, N. K. and Y. S. Lincoln. 2011. The SAGE Handbook of Qualitative Research. Thousand Oaks, CA: SAGE.

Fillieule, O. and C. Broqua. 2020. 'Sexual and Reproductive Rights Movements and Counter Movements from an Interactionist Perspective.' Social Movement Studies 19 (1): 1-20, https://doi.org/10.1080/14742837.2019.1709434.

Frye, N. 1976. The Secular Scripture. Cambridge, MA: Harvard University Press.

Gajdoš, A. and I. Rapošová. 2018. 'Juggling Grammars, Translating Common-place: Justifying an Anti-liberal Referendum to a Liberal Public.' European Journal of Cultural and Political Sociology 5 (1-2): 165-193, https://doi.org/10.1080/23254823.2018.1436448.

Geertz, C. 1973. The Interpretation of Cultures: Selected Essays. New York: Basic Books.

Giebel, K. and G. Röhrborn. 2014. 'Gender/Backlash. In the Wake of Yet Another Conservative Revolution.' Pp. 7-10 in Anti-Gender Movements on the Rise? Strategising for Gender Equality in Central and Eastern Europe, edited by E. Aghdgomelashvili et al. Berlin: Heinrich Böll Foundations.

Harari, Y. N. 2019. '50 Years after Stonewall: Yuval Noah Harari on the New Threats to LGBT Rights.' The Guardian, 22 June. Retrieved 7 September 2019 (https://www.theguardian.com/books/2019/jun/22/fifty-years-after-the-stonewallriots-yuval-noah-harari-on-the-new-threats-to-lgbt-freedom).

Hobsbawm, E. 2000. 'Introduction: Inventing Traditions' Pp. 1-14 in The Invention of Tradition, edited by E. Hobsbawm and T. Ranger. Cambridge: Cambridge University Press.

Jacobs, R. N. 2001. 'The Problem with Tragic Narratives: Lessons from the Los Angeles Uprising.' Qualitative Sociology 24 (2): 221-243, https://doi.org/10.1023/A:1010774209910.

Jameson, F. 2001. 'The Political Unconscious: Narrative as a Socially Symbolic Act' Pp. 101-107 in The New Social Theory Reader: Contemporary Debates, edited by S. Seidman and J. C. Alexander. London: Routledge.

Jaspers, J. M., J. Goodwin and F. Polletta. 2001. Passionate Politics: Emotions and Social Movements. Chicago, IL: University of Chicago Press.

Jaspers, J. M. 2009. 'Cultural Approaches in the Sociology of Social Movements' Pp. 59-110 in Handbook of Social Movements across Disciplines, edited by B. Klandermans and C. Roggeband. New York, London: Springer.

Kahlina, K. 2015. 'Local Histories, European LGBT Designs: Sexual Citizenship, Nationalism, and "Europeanisation" in Post-Yugoslav Croatia and Serbia.' Women's Studies International Forum 49: 73-83, https://doi.org/10.1016/j.wsif.2014.07.006. 
Kane, A. E. 1997. 'Theorizing Meaning Construction in Social Movements: Symbolic Structures and Interpretation during the Irish Land War, 1879-1882.' Sociological Theory 15 (3): 249-276, https://doi.org/10.1111/0735-2751.00034.

Kaufmann, J.-C. 2010. Chápající rozhovor (L’Entretien Compréhensif). Prague: Sociologické nakladatelství.

Konferencia biskupov Slovenska. 2013. Pastiersky list Konferencie biskupov Slovenska na Proú adventnú nedel'u (Pastoral letter of the Conference of Bishops of Slovakia for the first Sunday of Advent) 1 December. Retrieved 20 August 2017 (https://www. kbs.sk/obsah/sekcia/h/dokumenty-a-vyhlasenia/p/pastierske-listy-konferenciebiskupov-slovenska/c/pastiersky-list-na-prvu-adventnu-nedelu-2013).

Korolczuk, E. 2016. 'The Vatican and the Birth of Anti-Gender Studies.' Religion E Gender 6 (2): 293-296, https://doi.org/10.18352/rg.10181.

Kováts, E. 2017. 'The Emergence of Powerful Anti-Gender Movements in Europe and the Crisis of Liberal Democracy.' Pp. 175-189 in Gender and Far Right Politics in Europe, edited by M. Koettig, R. Bitzan and A. Pető. London: Palgrave Macmillan.

Krošlák, D. 2015. 'The Referendum on the So-called Traditional Family in the Slovak Republic.' Central and Eastern European Legal Studies 1: 149-167.

Kużelewska, E. 2019. ,Same-Sex Marriage - A Happy End Story? The Effectiveness of Referendum on Same-Sex Marriage in Europe.' Białostockie Studia Prawnicze 24 (1): 13-27, https://doi.org/10.15290/bsp.2019.24.01.01.

Lévi-Strauss, C. 1974. Tristes Tropiques. New York: Atheneum.

Libáková, L., V. Valkovičová and A. Jesenková. 2019. "'Deti v tom majú jasno!": Sexuálna výchova a etika starostlivosti v naratívoch slovenského "Referenda o rodine" v roku 2015.' ('The kids know what's what': sex education and the ethics of concern in narratives on the Slovak 'Referendum on the Family' in 2015) Gender a výzkum 20 (1): 128-148, https://doi.org/10.13060/25706578.2019.20.1.466.

Lučanič, I. 2015. 'Homoaktivisti: Chromík mal pravdu (komentár).' (Homoactivists: Chromík was right) Postoj, 15 May. Retrieved 31 May 2019 (https://www.postoj.sk/4550/homoaktivisti-chromik-mal-pravdu-komentar)

Mannheim, K. 1936. Ideology and Utopia: An Introduction to the Sociology of Knowledge. New York: Harvest.

McCutcheon, M. T. 1997. Manufacturing Religion: The Discourse on Sui Generis Religion and the Politics of Nostalgia. Oxford: Oxford University Press.

Mendelová, E. 2014. 'Súčasná postmoderná rodina a vnútrorodinná del'ba práce.' (The contemporary post-modern family and the within-family division of labour) Sociální pedagogika 2 (1): 11-21, https://doi.org/10.7441/soced.2014.02.01.01

Mesežnikov, G. 2015. 'Slovakia: Causes of the Referendum Fiasco.' Heinrich Böll Stiftung, 12 February. Retrieved 25 June 2019 (http://cz.boell.org/en/2015/02/12/slovakiacauses-referendum-fiasco).

Možný, I. 2002. Sociologie rodiny. (The sociology of the family) Prague: Sociologické nakladatelství.

Nejdeme.sk. 2015. Nejdeme.sk: Na zlé otázky neexistujú správne odpovede. (There are no right answers to bad questions) Retrieved 25 July 2019 (http://www.nejdeme.sk/)

O médiách.com. 2015. 'Zástupcovia LGBTI odmietajú íst' do diskusií s Alianciou za rodinu.' (LGBTI representatives refuse to enter discussions with the Alliance for the Family) O médiách.com: Marketing, 23 January. Retrieved 5 July 2019 (https://www.omediach.com/marketing/item/5859-zastupcovia-lgbti-odmietaju-istdo-diskusii-s-alianciou-za-rodinu).

Ocilková, R. 2014. 'Čo sa na nás chystá?!' (What are they planning for us?!) Blog SME, 12 December. Retrieved 25 June 2019 (https://ocilkova.blog.sme.sk/c/370308/co-sa-na-nas-chysta.html). 
O'Dwer, C. 2012. 'Does the EU Help or Hinder Gay-Rights Movements in PostCommunist Europe? The Case of Poland.' East European Politics 28 (4): 332-352, https://doi.org/10.1080/21599165.2012.721094.

Ondrejkovič, P. and J. Majerčíková. 2006. 'Zmeny v spoločnosti a zmeny v rodine kontinuita a zmena. Príspevok k diskusii o charaktere rodiny na Slovensku.' (Changes in society and changes in the family - continuity and change. A contribution to the discussion of the nature of the family in Slovakia) Sociológia 38 (1): 5-30.

Ondrušek, D., Z. Fialová, P. Guštafík, K. Miková, Z. Pauliniová and B. Smieška. 2017. 'Je slovenská spoločnost' na križovatke? Trendy a výzvy na základe kvalitatívnych ukazovatelov.' (Is Slovak society at a crossroads? Trends and challenges according to qualitative indicators) Pp. 89-106 in Občianska spoločnost' na Slovensku: Krízy, križovatky, výzvy, edited by G. Mesežnikov and B. Strečanský. Bratislava: Inštitút pre verejné otázky.

Paternotte, D. 2016. 'The NGOization of LGBT Activism: ILGA-Europe and the Treaty of Amsterdam.' Social Movement Studies 15 (4): 388-402, https://doi.org/10.1080/14742837.2015.1077111.

Paternotte, D. and R. Kuhar. 2017. "'Gender Ideology” in Movement: Introduction.' Pp. 1-22 in Anti-gender Campaigns in Europe: Mobilising Against Equality, edited by R. Kuhar and D. Paternotte. London and New York: Rowman \& Littlefield.

Patton, M. Q. 2002. Qualitative Research E Evaluation Methods: Integrating Theory and Practice. Thousand Oaks, CA: SAGE.

Pietruchová, O. 2014. 'Rodová ideológia? Nie, iba spravodlivost' a fair-play pre naše dcéry.' (Family ideology? No, just justice and fair play for our daughters) Blog SME, 11 November. Retrieved 25 June 2019 (https://pietruchova.blog.sme.sk/c/368906/ rodova-ideologia-nie-iba-spravodlivost-a-fair-play-pre-nase-dcery.html).

Polletta, F. 2006. It Was Like a Fever: Storytelling in Protest and Politics. Chicago, London: University of Chicago Press.

Polletta, F. and P. C. Bobby Chen. 2011. 'Narrative and Social Movements' Pp. 487-506 in The Oxford Handbook of Cultural Sociology, edited by J. C. Alexander, R. Jacobs and P. Smith. Oxford: Oxford University Press.

Prostredník, O. 2017. 'V otázke homosexuality stojí krestáanstvo na križovatke' (Christianity is at a crossroads on the issue of homosexuality) Komentáre SME, 22 August. Retrieved 27 June 2019 (https://komentare.sme.sk/c/20631887/v-otazkehomosexuality-stoji-krestanstvo-na-krizovatke.html\#ixzz5pyhkXPPR)

Reed, I. A. 2011. Interpretation and Social Knowledge: On the Use of Theory in the Human Sciences. Chicago, IL: University of Chicago Press.

Rapley, T. 2014. 'Sampling Strategies in Qualitative Research.' Pp. 49-63 in The SAGE Handbook of Qualitative Data Analysis, edited by U. Flick. London: SAGE.

Raučinová, M. 2014. 'Kto nás polarizuje na homofriendly a homophobic?' (Who is polarising us into homo-friendly and homo-phobic?) Postoj: konzervatíuny denník, 5 February. Retrieved 5 September 2018 (https://www.postoj.sk/3549/kto-nas-polarizuje-na-homofriendly-a-homophobic).

Ricoeur, P. 1973. 'The Model of the Text: Meaningful Action Considered as Text.' New Literary History 5 (1): 91-117.

Rybár, M. and A. Šovčíková. 2016. 'The 2015 Referendum in Slovakia.' East European Quarterly 44 (1-2): 79-88, https://doi.org/10.2139/ssrn.3014319.

Saussure, F. 1959. A Course in General Linguistics, edited by C. Bally and A. Sechehaye. New York: Philosophical Library.

Sekerák, M. 2015. “"Homoloby” ve “vatikánské gubernii”: Agonistická demokracie v praxi? Politické dimenze současné diskuse o homosexualitě na Slovensku.' (The 'homo-lobby' in Vatican City: agonist democracy in practice? The political 
dimension of the current discussion of homosexuality in Slovakia) Auspicia 11 (3-4): 22-54.

Sekerák, M. 2017. 'Same-Sex Marriages (or Civil Unions/Registered Partnerships) in Slovak Constitutional Law: Challenges and Possibilities.' Utrecht Law Review 13 (1), 34-59, http://doi.org/10.18352/ulr.340.

Slootmaeckers, K. and I. Sircar. 2018. 'Marrying European and Domestic Politics? The Marriage Referendum in Croatia and Value-Based Euroscepticism.' Europe-Asia Studies 70 (3): 321-344.

Smith, P. 2005. Why War? The Cultural Logic of Iraq, the Gulf War and Suez. Chicago, IL: University of Chicago Press.

Smrek, M. 2015. 'The Failed Slovak Referendum in "Family": Voters Apathy and Minority Rights in Central Europe.' Baltic Worlds, 4 March. Retrieved 2 February 2020 (http://balticworlds.com/the-failed-slovak-referendum-on$\%$ E2\%80\%9Cfamily\%E2\%80\%9D/).

Snow, D. A. and R. D. Benford. 2000. 'Framing Process and Social Movements: An Overview and Assessment.' Annual Review of Sociology, 26: 611-639.

SODB. 2011. Obyvatel'stvo podla pohlavia a náboženského vyznania (Population by sex and religion). Retrieved 4 September 2018 (https://census2011.statistics.sk/tabulky. html).

Spáč, P. 2010. Priama a zastupitel’ská demokracia na Slovensku: Volebné reformy a referendá po roku 1989. (Direct and representative democracy in Slovakia: electoral reforms and referenda after 1989) Brno: CDK.

Spillman, L. 2002. 'Introduction: Culture and Cultural Sociology.' Pp. 1-15 in Cultural Sociology, edited by L. Spillman. Oxford: Blackwell Publishers Ltd.

Swidler, A. 1986. 'Culture in Action: Symbols and strategies.' American Sociological Review 51 (2): 273-286, https://doi.org/10.2307/2095521.

Thornberg, R. and K. Charmaz. 2014. 'Grounded Theory and Theoretical Coding.' Pp. 153-169 in The SAGE Handbook of Qualitative Data Analysis, edited by U. Flick. London: SAGE.

Tódová, M. 2015. 'Anton Chromík: Tu nikto nikoho nikam nevyváža.' (Anton Chromík: no one is taking anyone anywhere here) Dennik N, 3 February. Retrieved 5 September 2018 (https://dennikn.sk/39432/anton-chromik-tu-nikto-nikoho-nikam-nevyvaza/).

Ullrich, P., P. Daphi and B. Baumgarten. 2014. 'Protest and Culture: Concepts and Approaches in Social Movement Research - An Introduction.' Pp. 1-20 in Conceptualizing Culture in Social Movement Research, edited by B. Baumgarten, P. Daphi and P. Ullrich. London: Springer.

Valkovičová, V. 2017. "“Regrettably, It Seems That Breaking One Border Causes Others to Tumble": Nationalism and Homonegativity in the 2015 Slovak Referendum.' Politique Européenne, 55 (1): 86-115, https://doi.org/10.3917/poeu.055.0086.

Wagner, P. 1994. A Sociology of Modernity: Liberty and Discipline. London: Routledge.

White, H. 1980. 'The Value of Narrativity in the Representation of Reality.' Critical Inquiry 7 (1): 5-27. 